\title{
RESEARCH ON THE LOCALIZATION METHOD OF PROTECTING TRADITIONAL VILLAGE LANDSCAPE: A CASE STUDY ON TANGYIN
}

\author{
Li Wei ${ }^{\mathrm{a}}$ \\ a. Tsinghua Heritage Institute For Digitization, Shangdi West Street, Beijing,-liwei@thid.cn
}

KEY WORDS: Landscape Protection, Traditional Village, Landscape Localization, Tangyin

\begin{abstract}
:
China has over 271 million villages and less than the number in ten years ago in which there are 363 million villages. New rural construction indeed do some good for common villages but still destroy hundreds and thousands traditional village which contain great cultural, science, artistic values. In addition, traditional villages can't meet the increasing needs in more convenient and comfortable living conditions. Increasing population also makes traditional villages out of control in construction. With the background of this, we have to set up in traditional village protection. This article put forward an idea in protection which make use of landscape localization to pursue the sustainable development and vernacular landscape protection. Tangyin Town is a famous trade center in history and left many cultural heritage, especially historical buildings. Take Tangyin as a case study to apply the localization method which could guide other similar villages to achieve same goals.
\end{abstract}

\section{INTRODUCTION}

For thousand years, traditional village represent Chinese people life style and create profound vernacular civilization. It has extreme significance in history, art, science, technology, architecture, aesthetics, landscape, ecology, philosophy and so on. There are over five thousand traditional villages all over the nation out of 270 million ones. Most of them distribute in economically backward area. From 2009 to 2010, Chinese Village Culture Research Centre investigated 17 provinces nationwide and then statistics showed that traditional villages had been reduced from 9707 to 5709 which means there were 1.6 villages was disappearing every day in that one year (Zhou Qiansong,2013 ) . In 2012, there are three nation departments put forward a program that named Chinese traditional village which aim at protecting those villages that own abundant values. Up until now, there are 2555 villages have been enrolled in the Chinese traditional village list. This program includes general survey which is a significant work in the context of rapid urbanization which made traditional villages fading away can help understanding the current situation and then raise guidance on how to protect. Essentially, the apparent phenomenon is the traditional village landscape has changed with historical architectures which may even be important heritage being razed. Currently the main problem of village landscape are that tanglesome architecture style, environment pollution and low ratio of green area along with being short of public space. Tangyin town governs fourteen administrative villages which including three traditional villages named respectively Jiefang Village, Mingzhu Village, Jianshe Village. This three villages are part of third group of Chinese traditional village which announced in November 2014. These villages urbanization rate has reached about $34 \%$. Along with years construction many old buildings had been destroyed and more modern multideck buildings instead.

There are many reasons that made traditional village disappear, except for urbanization, such as young adults leaving for working, requirement for more well-suited living conditions, traditional village pattern can't match traffic function, villager lack of consciousness on protection. Indeed traditional village has its own weakness. Historical buildings are commonly facing for long years out of repairing and lack of basic living facilities like bathroom. Especially in needy area those problem will be magnified. Traditional village protection is unlike other cultural heritage which need to considerate the people, including their life condition and village development. The core point of protecting village landscape is that keeping humanity spirit and activity.

\section{LITERATURE RESERCH}

\subsection{Village Landscape}

In recent years at the research of village landscape overseas scholars focused mainly on the landscape assessment, landscape management and landscape transition. They preferred combine the ecotope with the settlement environment and try to use social and cultural elements to explain the landscape transition. Also they had an interest in the influence from human behaviour on landscape (Zhou Xinqin, 2007). Melissa(2012) analysed the reason of village landscape transition which come from road construction, transformation of building materials, higher living level, inflection of family structure and social relationship, different culture self-identity.

Domestic researchers studied village landscape began with heritage protection and then gradually transformed from village building to more diverse aspect, like landscape transition, aesthetics, psychology.

\subsection{Landscape Localization}

Localization is a relative concept to globalization. Researchers pay more attention in urban landscape localization to chase a more harmony and ecological environment. Making use of local plant to Meanwhile, studies on local culture is also common with analysing the culture features of village and the relationship between it and local landscape.

\subsection{Traditional Village Protection}

In the beginning of research on protection of traditional village was focus on the Historical and Cultural Village. Especially after Xidi and Hongcun Village being enrolled in the world cultural heritage list, more researchers had been studying the values of traditional village and protection mode.

\section{PROTECTING OF TRADITIONAL VILLAGE}

The protection process in traditional village is similar all over the world on which from single architecture to integrate area. Heritage protection was beginning earlier in the west and there are many laws and treaties have been come up. There are three process of heritage protection in China. First period is from 1950s to 1980 s in which the key point is to protect historical relic including vernacular buildings. The second period is from $1980 \mathrm{~s}$ to the middle 1990s in which our nation created historical cultural 
city system which means the protection had focus on integrity area. The last period is from the beginning of 21 th century until now in which we have built multi-level protection system which concern on historical cultural town, village and street.

Along with the improvement of law system, the planning of traditional village had been starting around the nation. And also many places launched 'beautiful village construction program'.

\section{CONCEPT OF LOCALIZATION}

Landscape localization of traditional village is a method to protect village heritage in a more harmony way and have an emphasis on sustainable development.

\subsection{Definition Comparison}

Localization is a relative concept to globalization that concerns on adapting to the indigenous culture, economy and politics and respects the uniqueness of landscape, resources, material, custom, and so on. Most of Chinese traditional villages that been constructed by aboriginals whom had know well about the natural resource with perennial exploration in a creative and harmony way.

Vernacular originates from 'vernaculus' that including several features like anonymous, spontaneous, and officious in the architecture filed. This concept focus on the aborigine's creation. Ruralization is a relative concept to urbanization that focus on the effect of economic. Generally speaking, population change is one of the most important factor to evaluate the ruralization level. Localization and vernacularism are different from ruralization that prefer to combine the regional features and customs.

\subsection{Meaning}

(1)Landscape localization will help sustain and inherit local culture.

(2)Help reconstruct vernacular nature that can promote integration of human and nature.

(3)Help promote the renaissance of village common life and production to make countryside develop healthier.

(4)Satisfy city resident spiritual needs like reminiscence, seeking root, soul return and so on.

\section{STUDY AREA}

\subsection{Tangyin Town}

Tangyin Town locates in Yihuang county of Fuzhou City, Jiangxi Province, which in the middle of China and is about $13 \mathrm{~km}$ away from county centre and $80 \mathrm{~km}$ away from the downtown. The scale of township region is about 56.5ha. The percent of residential land is 55\% which exceeds the standard (28\%-38\%). The study area includes three village in the township region that is Jiefang Village, Mingzhu Village and Jianshe Village which totally have a population of about 4700 . The leading industry of Tangyin is primary industry that is a typical agricultural trade town. The villages are surrounded by hills and a river called Yishui flows across the west. This area is humid subtropical monsoon climate with warm and sunny weather and plenty of rainfall. So flood is the most dangerous threat here.

In history, in Qing Dynasty, due to the clean river water and appropriate soil for planting ramie which is the raw material grass cloth, Tangyin was one of three big producing-area in middle of China that abounds in grass cloth. With the grass cloth business had been developing, Tangyin was gradually become a trade centre in that region, except for selling grass cloth but local farm production and other goods from outside. Economic development drive the village construction. Stores, residences, academies, ancestral halls had been built and population was growing to 120000 .

Now the historical buildings in the villages most date from the Qing Dynasty which is around 300 years ago.

Table1. Relative Data of Tangyin Town

\begin{tabular}{|c|c|c|c|c|}
\hline Village & Jiefang & Mingzhu & Jianshe & Tangyin \\
\hline Population & 1659 & 988 & 2002 & 18387 \\
\hline $\begin{array}{c}\text { agricultural } \\
\text { scale/ha }\end{array}$ & 213.4 & 98.7 & 249.1 & 2128.9 \\
\hline $\begin{array}{c}\text { Household } \\
\text { per person } \\
\text { annual } \\
\text { income/yuan }\end{array}$ & 5290 & 256 & 519 & 4246 \\
\hline $\begin{array}{c}\text { Main Industrial } \\
\text { output/million } \\
\text { yuan }\end{array}$ & 1630 & 850 & 4870 & 5300 \\
\hline
\end{tabular}

\subsection{Village Landscape Classification}

Traditional village is that those historical village remains intact village environment, buildings, traditional atmosphere and historical cultural features. According to the definition of traditional village, we can divide four classes with 18 subclasses. Different from other classification of village landscape.

Surrounding natural landscape mainly mean those original ecology environment which is the normalized factor that affects the traditional village formation and also is the key factor that drives the regional disparity.

Rural producting and living landscape bases on farmland and settlement landscape that is a dynamic landscape and reflects rural routines and local authenticity.

Rural settlement and architecture landscape bases on nature and is a kind of man-made landscape containing persistence and identification(Weng Youzhi, 2008). It is the core landscape that reflects the functionality and cultural attributes of local landscape. Traditional culture and folk-custom landscape based on local knowledge and is a kind of social cultural landscape which divided itself with the political landscape that shows folk attributes and nation characters.

\begin{tabular}{|c|c|}
\hline \multicolumn{2}{|c|}{ Table2. Definition of Traditional Village } \\
\hline pointcut & definition \\
\hline $\begin{array}{l}\text { cultural } \\
\text { heritage }\end{array}$ & $\begin{array}{l}\text { Traditional village contains abundant material } \\
\text { and nonmaterial cultural heritage, that belongs } \\
\text { to historical heritage system and shows } \\
\text { human's living trace with aesthetic, cultural, } \\
\text { philosophical values. }\end{array}$ \\
\hline period & $\begin{array}{l}\text { Traditional village is that those village at less } \\
\text { retain from Ming and Qing Dynasty; or the } \\
\text { village date from before the period of the } \\
\text { Republic of China. }\end{array}$ \\
\hline $\begin{array}{l}\text { anthropo- } \\
\text { sociology }\end{array}$ & $\begin{array}{l}\text { Traditional village is a regional settlement } \\
\text { come from the interaction of human and nature } \\
\text { with social and cultural values. }\end{array}$ \\
\hline $\begin{array}{l}\text { Inherit } \\
\text { and } \\
\text { integrity }\end{array}$ & $\begin{array}{l}\text { Traditional village is that those village retain } \\
\text { long history and intact material cultural } \\
\text { heritage with evident local characteristics. }\end{array}$ \\
\hline $\begin{array}{l}\text { Historical } \\
\text { vernacular } \\
\text { building }\end{array}$ & $\begin{array}{l}\text { Traditional village is that those village has } \\
\text { concentrated area with historical building and } \\
\text { vernacular building of which quantity occupies } \\
\text { one third of the whole buildings' quantity of }\end{array}$ \\
\hline
\end{tabular}




\begin{tabular}{|c|c|c|}
\hline & \multicolumn{2}{|c|}{$\begin{array}{l}\text { the village and shows particular historical } \\
\text { period traditional landscape. }\end{array}$} \\
\hline \multicolumn{3}{|c|}{ Table3. Classification of the traditional village landscape } \\
\hline Property & class & subclass \\
\hline \multirow[t]{3}{*}{$\begin{array}{l}\text { Tangible } \\
\text { landscape }\end{array}$} & $\begin{array}{l}\text { Surrounding } \\
\text { natural } \\
\text { landscape }\end{array}$ & $\begin{array}{l}\text { geomorphologic landscape, } \\
\text { waterscape, climatic } \\
\text { scenery(misty landscape), local } \\
\text { flora and fauna, colorscape }\end{array}$ \\
\hline & $\begin{array}{l}\text { Rural } \\
\text { producting } \\
\text { and living } \\
\text { landscape }\end{array}$ & $\begin{array}{c}\text { farmland, farming } \\
\text { landscape(farm tools, farm } \\
\text { products, cultivation scenery) } \\
\text { rural common life activity(fetch } \\
\text { water, chop firewood, breeding, } \\
\text { recreation activity etc.) }\end{array}$ \\
\hline & $\begin{array}{l}\text { rural } \\
\text { settlement } \\
\text { and } \\
\text { architecture } \\
\text { landscape }\end{array}$ & $\begin{array}{l}\text { Settlement pattern(spatial } \\
\text { arrangement and site selection, } \\
\text { water gate, street pattern), } \\
\text { residential building, architecture } \\
\text { art(painting, sculpture, } \\
\text { calligraphy, etc,), living } \\
\text { facility(road and bridge, dock, } \\
\text { store, station, etc.), spiritual and } \\
\text { cultural facility ( ancestral hall, } \\
\text { temple, pavilion, stage, } \\
\text { memorial archway, gatehouse, } \\
\text { academy, square ) }\end{array}$ \\
\hline $\begin{array}{l}\text { Intangible } \\
\text { landscape }\end{array}$ & $\begin{array}{l}\text { Traditional } \\
\text { culture and } \\
\text { folk-custom } \\
\text { landscape }\end{array}$ & $\begin{array}{l}\text { agricultural civilization, } \\
\text { religious faith, religious culture, } \\
\text { vernacular custom, folk } \\
\text { knowledge and technology, } \\
\text { countryside atmosphere }\end{array}$ \\
\hline
\end{tabular}

\subsection{Features of Village Landscape in Tangyin}

\subsubsection{Surrounding natural landscape}

Waterscape: Yishui River flows across the township and the three village from north to west are respectively Jiefang Village, Jianshe Village, Mingzhu Village.

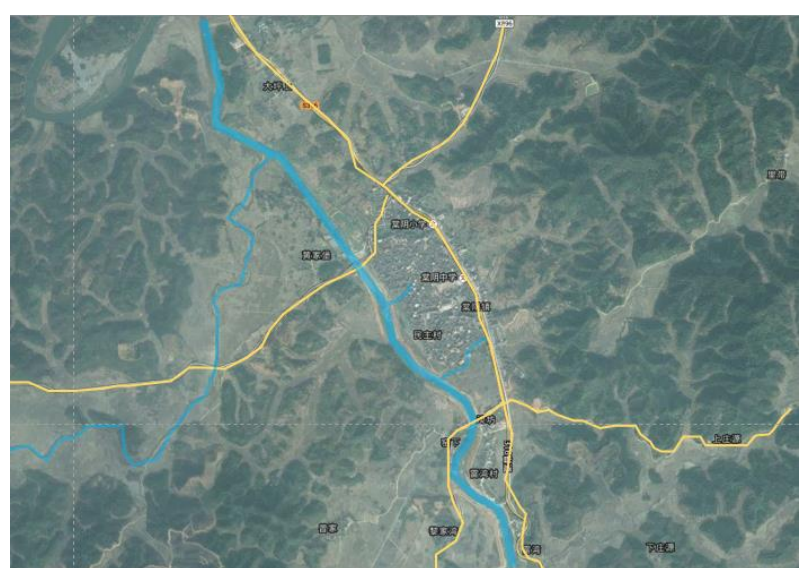

Figure1. Satellite Imagery of Tangyin Township (Picture source: self-drawing)

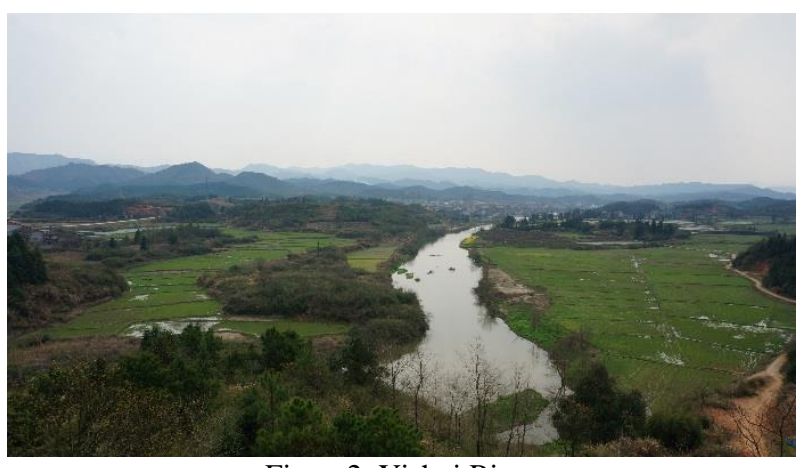

Figure2. Yishui River

(Picture source: self-photographing)

\subsubsection{Rural producing and living landscape}

There is about 800 acre farmland in Tangyin Town and the main farm production are rice, tobacco, white lotus and sweet potato. In this area there is also many lotus ponds and fish ponds.

The proportion of agricultural population in the villages is about $79 \%$ and the cultivating scene is common around the margin area and inner field. The other producing activities include making sweet potato noodle, raising pigs and ducks.

Lacking of public space makes most of villagers having activities just in themselves' yard or the field in the front of the house. The common activities are chatting, resting, handworking. Also you will see some women washing cloth besides the river.

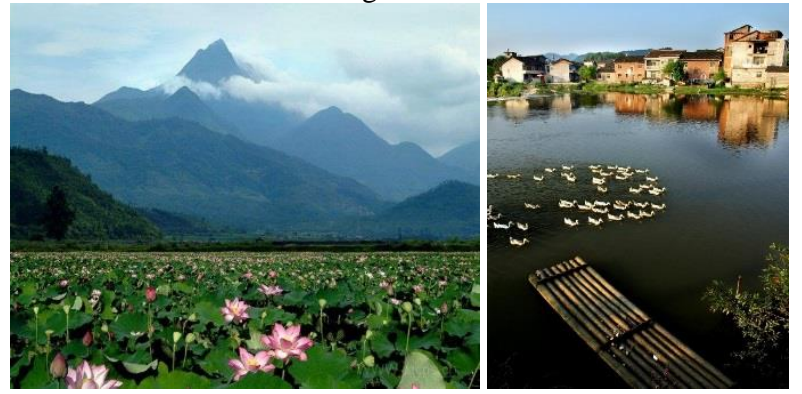

Figure3. Ponds In The Villages

(Picture source:download from www.baidu.com)

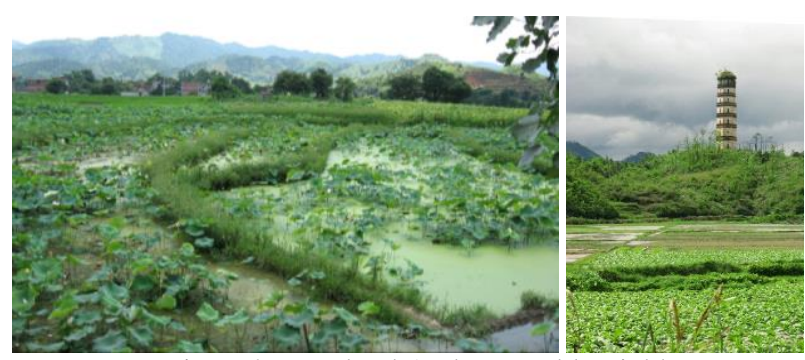

Figure4. Farmland And Vegetable Field

(Picture source:download from www.baidu.com)

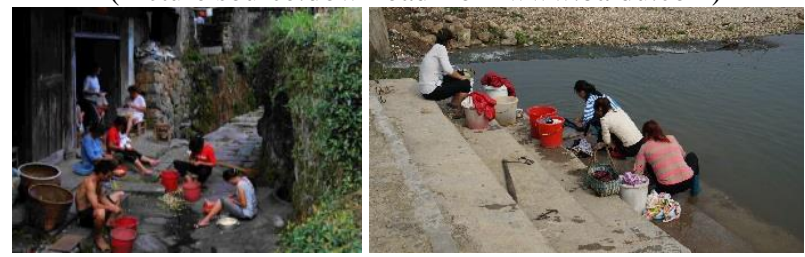

Figure5. Common Activities

(Picture source: self-photographing)

\subsection{3 rural settlement and architecture landscape}

Site selection of the villages reflects the Chinese traditional theory: Fung shui, literally wind and water, which is a geomantic doctrine providing a complicated set of interacting guidelines for the placing of villages, for the building of houses and for the orientation of all manner of products serving the living and dead. 
The basic principle of site selection is fronting water and with hills on the back which means hiding wind and gather spirit. Functionally, the place surrounded by hills can resist severe weather and providing suitable natural condition for cultivating. Meanwhile, closed space makes people feeling more security and sense of occupation.

Tangyin was exactly match the principle and shows advantages on Fung shui theory.

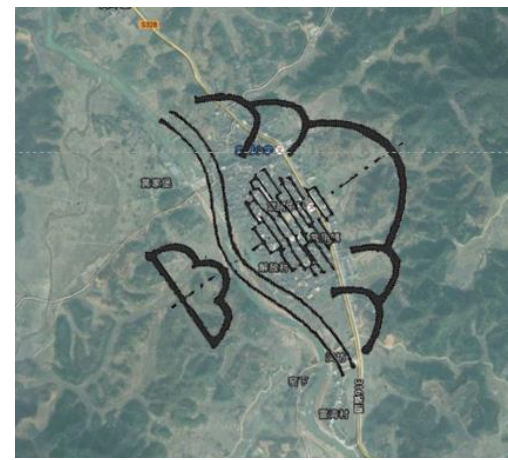

Figure6. Fung Shui principle on the site selection (Picture source: self-drawing)

Historical residential buildings in Tangyin reflects classical features of the architecture of south Jiangxi, a province in the middle of China. The most important feature of this type residential building is the courtyard which help to get daylight and collect rainwater. In Tangyin, the number of the yard represent the levels of wealth. There are different types of courtyard. One called slide-open courtyard which can make use of a mobile shed to adjust the daylight and enhance the effect of abundant light. Another type call soil shape courtyard which have embossment platform in the middle of the land.
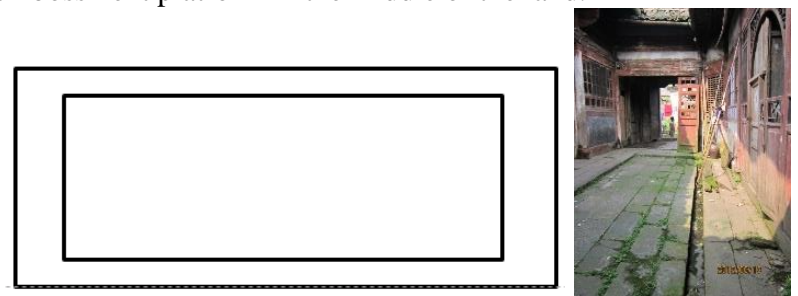

Figure7. Soil Shape Courtyard

(Picture source: self-drawing and self-photographing)
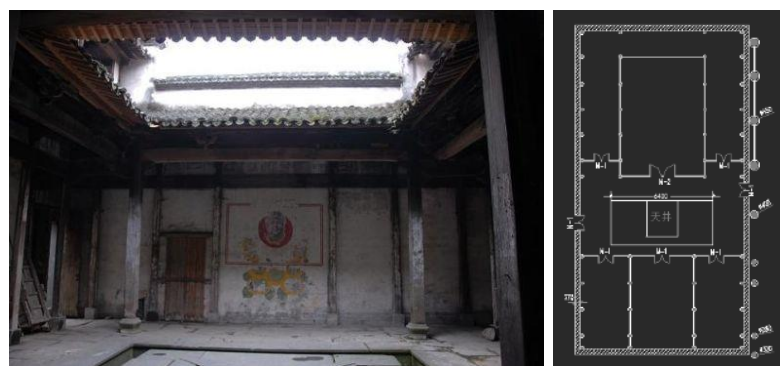

Figure8. Courtyard

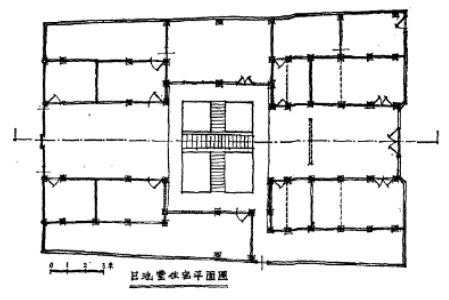

Figure8. The Plan of Ri Shape Building in Tangyin

(Picture source: Shao Zengze, 1982 )

The column-and-tie construction is commonly used here and pay more attention to the internal structure and practical ornament. Bafujun ancestral hall mixes the column-and-tie construction and the post-and-lintel construction, the latter make the middle space more tall and huge.

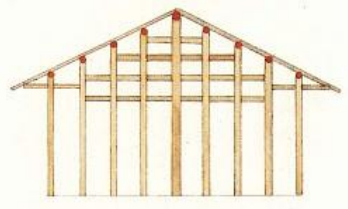

穿斗武构策

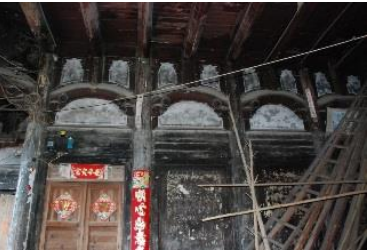

lumn-and-tie Construction

(Picture source: download from internet and self-photography )

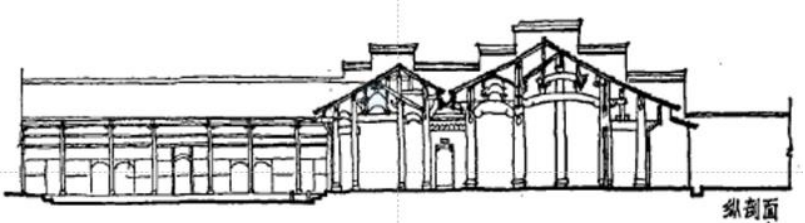

Figure10. The Profile of Bafujun ancestral hall in Tangyin (Picture source: Shao Zengze, 1982 )

Architecture art here most are painting and sculpture. However many painting had been destroyed in the past. But the wood sculpture also show high skill level. The sculptures always depict stories or blessing to the family. Brick carving are spread all around the villages which always show blessing and avoid bad things.
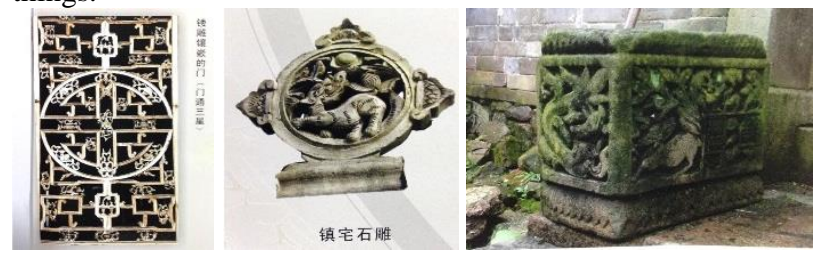

Figure11. Kinds of scupture

(Picture source:download from www.baidu.com)

The remain old buildings except for residential buildings are ancestral hall, academy, ancient tower and old-style bank, etc.

\subsubsection{Traditional culture and folk-custom landscape}

The most famous folk activity here is Tangyin Lantern date from Qing Dynasty in first month of the lunar year. Every household will make lantern by themselves and get on fire from the progenitor house which can be seen as the original house.

Yihuang opera is prevalent in Jiangxi Privince and has been about 400 years old dating from Ming Dynasty. It has been enrolled in the first group national intangible cultural heritage in 2006.

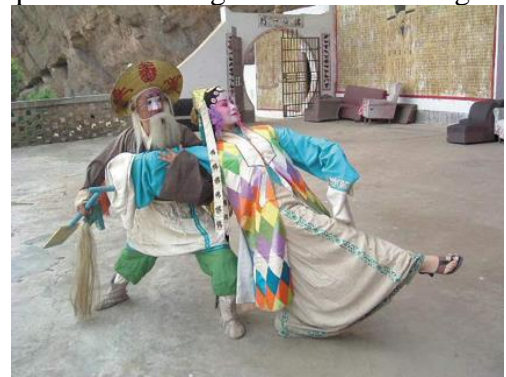

Figure12. Yihuang Opera

(Picture source:download from www.baidu.com) 


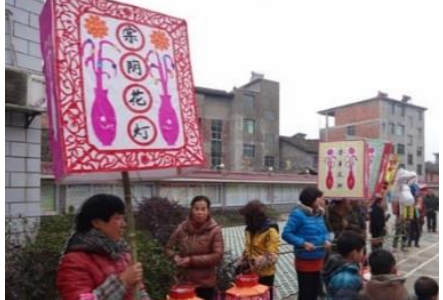

Figure13. Tangyin Lantern

(Picture source:download from www.baidu.com)

\subsection{Existing Problems}

Historical residential buildings has prominent features and part of them are kept well. However the integrity of the traditional village landscape is fade away with the long year breaking and lost culture connotation. In addition, regional poverty makes historical architecture protection more difficult. With the requirement in living villagers have to pull down old house to free up enough space for new house with more comfortable facility. But the outlook of the new building don't match the traditional village landscape and huge multi-storey buildings obstruct the relation with the past that effect the sense of the place in further. In fact large scale construction have made Tangyin becoming a crowd and disorder dwell. Population increasing one side needs more space to live, on the other side needs more space to host events and activities. Lacking of public space is the other major problem.

All in all, Tangyin is facing the most difficult problem in coordinating the contradiction between protection and development. Town development concern to the human's livelihood and have to hold internal culture. Localization may give a sustainable way to solve this puzzle.

\section{LOCALIZATION METHOD}

\subsection{Enhance local landscape factor}

Domestic researchers have made practice on applying traditional village landscape factors in city designing and planning. There are different ways to get the local village landscape and all have its own advantages and effects. We should use flexibly in the fact of the situation and

\begin{tabular}{|c|c|c|}
\hline \multicolumn{3}{|c|}{ Table4. Design Methods } \\
\hline approach & $\begin{array}{c}\text { Content } \\
\text { Imitating the factor of } \\
\text { local landscape, like } \\
\text { shape imitation, } \\
\text { structure imitation and } \\
\text { function imitation } \\
\text { imitation }\end{array}$ & $\begin{array}{c}\text { Keep the feature of } \\
\text { the factor and is } \\
\text { easy to achieve in } \\
\text { inherit the } \\
\text { traditional village } \\
\text { landscape feature } \\
\text { and be perceived }\end{array}$ \\
\hline redesign & $\begin{array}{c}\text { On the premise of } \\
\text { keeping original } \\
\text { meaning to design a new } \\
\text { landscape which is more } \\
\text { suitable to the current } \\
\text { needs }\end{array}$ & $\begin{array}{c}\text { This is a kind of } \\
\text { landscape update } \\
\text { and give tradition } \\
\text { now vitality and } \\
\text { adaptability. }\end{array}$ \\
\hline restoration & $\begin{array}{c}\text { Restore the degenerating } \\
\text { and declining traditional } \\
\text { landscape with artistic } \\
\text { designing }\end{array}$ & $\begin{array}{c}\text { Recall the memory } \\
\text { of the past }\end{array}$ \\
\hline
\end{tabular}

\subsection{Design Strategy}

Anti-planning Strategy

This theory is come up with a purpose that prevents city expansion and put emphasis on the consecutiveness and integrity of land use. Ecological environment that as the preferential planning factor in this theory shows the concerning on the relation of human and nature. It advocates the combination of nature, culture and landscape aesthetics (Yu kongjian, 2002). Therefore we should considering the landscape ecological pattern in prior with design non-construction land to preserve the earth landscape. $\mathrm{Yu}$ still propose take recreational value into consideration in order to protect cultural heritage better $(\mathrm{Yu}$ kongjian, 2005). So assessment on recreation value is necessary.

\section{Function-oriented Strategy}

Most of the traditional village landscape are fuction-based landscape(Zhang Tao, Su Jing, 2008). Function-oriented strategy advocates take human as the first consideration to stress the use of place and create fitting space.

\section{New-vernacular strategy}

New-vernacular comes from local landscape subject which is a new way in dealing with the landscape homogeneity under the background of the improvement of the global science and technology, as well as the global economic integration trend. The essence of new-vernacular is that using new technology, science, and resource on the premise of merging traditional style and meaning. New-vernacular reflects the characteristics of times and is a more adaptable design thought.

\subsection{Design emphasis}

Pay emphasis on rural producting and living landscape

This kind landscape is the key factor that distinguish from other cultural landscape. Agricultural landscape is the most important carrier of perceiving rural atmosphere(Wang Yongjing, 2012). People's preference on agricultural landscape is the basis of rural landscape aesthetic. In addition, peasant interact with the land, so we should take their common life as important factor on design.

Pay emphasis on booming Traditional culture and folk-custom landscape

In view of landscape perception and structure, traditional culture and folk-custom landscape is crucial. However the formation and meaning are declining gradually. So revitalizing this kind of nonmaterial cultural heritage becomes significant and we should design from the cultural landscape perception.

\section{Pay emphasis on making use of local resource}

It is an important way to localize the traditional landscape through making use of local plant and material. Local plant can adapt well here's climate, help develop local landscape and carry spiritual perception and memory. Moreover, local plant is a kind of symbol which represent the hometown to the local people. As to local material that is help to keep traditional features in construction and satisfy the yearn for the rural environment.

\section{Pay emphasis on imitation of traditional artistic conception}

Spiritual enjoyment has great influence on rural landscape perception. We should research on artistic sense of traditional countryside to extract landscape symbols to imitate. So we can see that people's perception is also an important factor in landscape designing.

\section{Tourism localization}


Some researchers think traditional village landscape is a kind of tourism resource and in the recent years rural tourism has developed fast. Rural tourism localization is part of rurality and economic system in local region. The main point is the local tourism economy development with resource localization and business localization. We should encourage local people getting jobs first and improve local commodity economy.

\subsection{Visual landscape control}

\section{Colour landscape control}

Colour landscape consists natural colour landscape and manmade colour landscape. The former is unstable and will change with climate and time. So designer should analyse natural colour and make the man-made colour match that. Moreover, colour landscape design still needs to considerate size, location and combination (Xian Ning, 2013). The first step is investigate the basic colour in the field and use these information to design vernacular architecture in the facade, roof and material selection.

\section{Settlement pattern control}

Appropriate area is important for rural settlement which shows the rurality and village features. The control of the settlement pattern mainly falls in the surrounding space and inner streets and public space design.

\section{Farmland protection}

Idyllic scenery is the most important factor of the traditional village landscape which primarily consists farmlands. Farmland has the most closed relation with the land and shows the relation of human and nature. Sometimes continuous and sizable farmland will give people visual impact.

\subsection{Community level}

In view of the folk feature we should take community into consideration by self-management.

Some scholars think the subject of the community participation is villagers have same approval in effective, reasonable and fair institution and resource arrangement (Qian Fawen, 2008). Villagers contact with the traditional landscape and have long years influence on it. We can use elite education mode to advocate the enthusiasm in protecting which need to foster individuals as leader to call on others. These people can drive more human resources. Education on the signification of the protecting heritage is also important which can improve people's cognition. In the current conditions, we should encouragement policies instead of simple punishment to improve positivity. We can divide two classes of the participation method which one is data collection and another is publicity and arousing. We must consider the differences of ages, education levels, gender, and psychological conditions. In the traditional villages, women, the aged and children are in the majority. We have to use suitable means to make the data more accuracy and effects more favourable.

Tab.8-5 Tools of Promoting Community Participation

\begin{tabular}{|c|c|}
\hline tools & $\begin{array}{c}\text { content } \\
\text { Painting }\end{array}$ \\
$\begin{array}{c}\text { Directly show the location of the } \\
\text { resources and their type, size, number. }\end{array}$ \\
\hline Season calendar & $\begin{array}{r}\text { Record festival, important activities, } \\
\text { cultivation calendar. }\end{array}$ \\
\hline peasant diary & $\begin{array}{c}\text { Record peasant's activity, a kind of } \\
\text { self-monitor }\end{array}$ \\
\hline
\end{tabular}

\begin{tabular}{|c|c|}
\hline $\begin{array}{l}\text { chronicle of } \\
\text { events }\end{array}$ & $\begin{array}{l}\text { Investigate the old people in the } \\
\text { villages to get information }\end{array}$ \\
\hline matrix & $\begin{array}{l}\text { Design matrix to know villagers' } \\
\text { cognition, understanding and attitude } \\
\text { on particular things }\end{array}$ \\
\hline $\begin{array}{l}\text { Marking and } \\
\text { ranking }\end{array}$ & $\begin{array}{l}\text { know villagers' cognition, } \\
\text { understanding and attitude on } \\
\text { particular things }\end{array}$ \\
\hline $\begin{array}{l}\text { semi-structured } \\
\text { interview }\end{array}$ & $\begin{array}{l}\text { Opening- chatting, create a relaxed } \\
\text { atmosphere to communicate with } \\
\text { villagers in order to decline their } \\
\text { resistant mind. }\end{array}$ \\
\hline $\begin{array}{l}\text { Key information- } \\
\text { man }\end{array}$ & Interview key person \\
\hline Key group & $\begin{array}{l}\text { Interview particular group, like } \\
\text { woman, governor. }\end{array}$ \\
\hline
\end{tabular}

\section{REFERENCE}

Zhou Qiansong. 2013. Current problem and thinking on Traditional village protection in China. Chinese Construction. 2(01), pp. 101.

Zhou Xinqin. 2007. Research on new progress of the west country village landscape. Regional research and development. (3), pp. 85-90.

Weng Youzhi. 2008. Vernacular settlement landscape in the north Guizhou Province. Nanjing University. pp. 9-11.

Qian Fawen. 2008. Community participation and wetland management. Science Press[Beijing]. pp. 41-59.

Yu Kongjian, Wang Zhifang.. Discussion on the vernacular landscape and its meaning for the modern landscape design. Central China Architecture. (4), pp. 123-126.

Yu Kongjian, Li Dihua. 2002. Discussion on the anti-planning and urban eco-basic facility construction. China association for science and technology. pp. 2-4.

Shao Zengze, Rao Xianggui, Wang Chunshui, Huang Zhenliang. 1982. Architecture history and theory. pp. 149-150.

Wang Yongjing. 2012. New rural landscape design. Zhejiang Agriculture and Forestry University. pp. 14-17.

Melissa Malouf Belz. 2012. Spirit of Place and the Evolution of the Vernacular House in Kinnaur, Himachal Pradesh, India. Oxford : Oxford Brookes University. pp. 7-12

Jean-Laurent Pfund, John Daniel Watts,et al. 2011.

Understanding and Integrating Local Perceptions of Trees and

Forests into Incentives for Sustainable Landscape Management. Environmental Management. 48, pp. 334-349. 